\title{
REFRACTION SEISMIC SOUNDINGS ON THREE CRAG AND TAIL RIDGES IN CENTRAL FINLAND
}

\author{
JORMA MÄKELÄ and KARI ILLMER
}

\begin{abstract}
MÄKELÄ, JORMA \& ILLMER, KARI, 1992: Refraction seismic soundings on three crag and tail ridges in Central Finland. Bull. Geol. Soc. Finland 64, Part 1, $23-33$.

In this study we describe the materials and thicknesses of tills in three crag and tail ridges located in Central Finland. According to the refraction seismic soundings the tills above the groundwater table are loose and sandy and their average seismic velocities are from 900 to $1200 \mathrm{~m} / \mathrm{s}$. The tills below the groundwater table are compact and sandy and their average seismic velocities are from 2000 to 2200 $\mathrm{m} / \mathrm{s}$. Below the highest shoreline of the Baltic Sea the tills are overlain by from 1 to $3 \mathrm{~m}$ thick shore deposits (washed tills). Their seismic velocities are from 330 to $870 \mathrm{~m} / \mathrm{s}$. The depth of the groundwater table in the ridge tails varies from 1 to $24 \mathrm{~m}$. The tills are $55 \mathrm{~m}$ at their thickest. They may be even thicker than that, perhaps $85 \mathrm{~m}$.
\end{abstract}

Key words: seismic surveys, refraction methods, drumlins, till, thickness, groundwater, Quaternary, Laukaa, Hankasalmi, central Finland

Jorma Mäkelä \& Kari Illmer: Water and Environment District of Central Finland, P.O. Box 110, SF-40101 Jyväskylä

\section{Introduction}

There are thousands of subglacially streamlined landforms in Central Finland, especially in the eastern part. Most of them are crag and tail ridges and belong to the Keitele-Pieksämäki drumlin field (see Glückert 1973, Mäkelä 1985, 1988). The size of the crag and tail ridges varies widely: length from 0.1 to $7 \mathrm{~km}$, width from 0.1 to $2 \mathrm{~km}$ and height from 1 to $120 \mathrm{~m}$.

Crag and tail ridges are elongate landforms which have a knob of bedrock (crag) at the stoss side and a streamlined slope (tail) at the lee side. The tail generally consists of till.

The Geological Survey of Finland has done seismic soundings on drumlins (e.g. HaavistoHyvärinen 1987, Haavisto-Hyvärinen et al. 1989,
Salmi et al. 1991). The purpose of these soundings was to investigate the soil and groundwater conditions of the drumlins. The soundings were mainly done with an explosive seismic equipment.

In this study we wanted to find out how thick the tills of the crag and tail ridges can be. We also hoped to get information about the soil and groundwater conditions of the crag and tail ridges. We were also interested in finding out the reliable depth of penetration of our hammer seismic equipment. It is generally believed that the maximum reliable depth of penetration is not more than 10 m (e.g. Peltoniemi 1988). Recent studies show, however, that it is possible to get information about soil conditions 30 meters below the ground surface or even deeper (e.g. Mäkelä et al. 1990, Ristaniemi et al. 1991). 


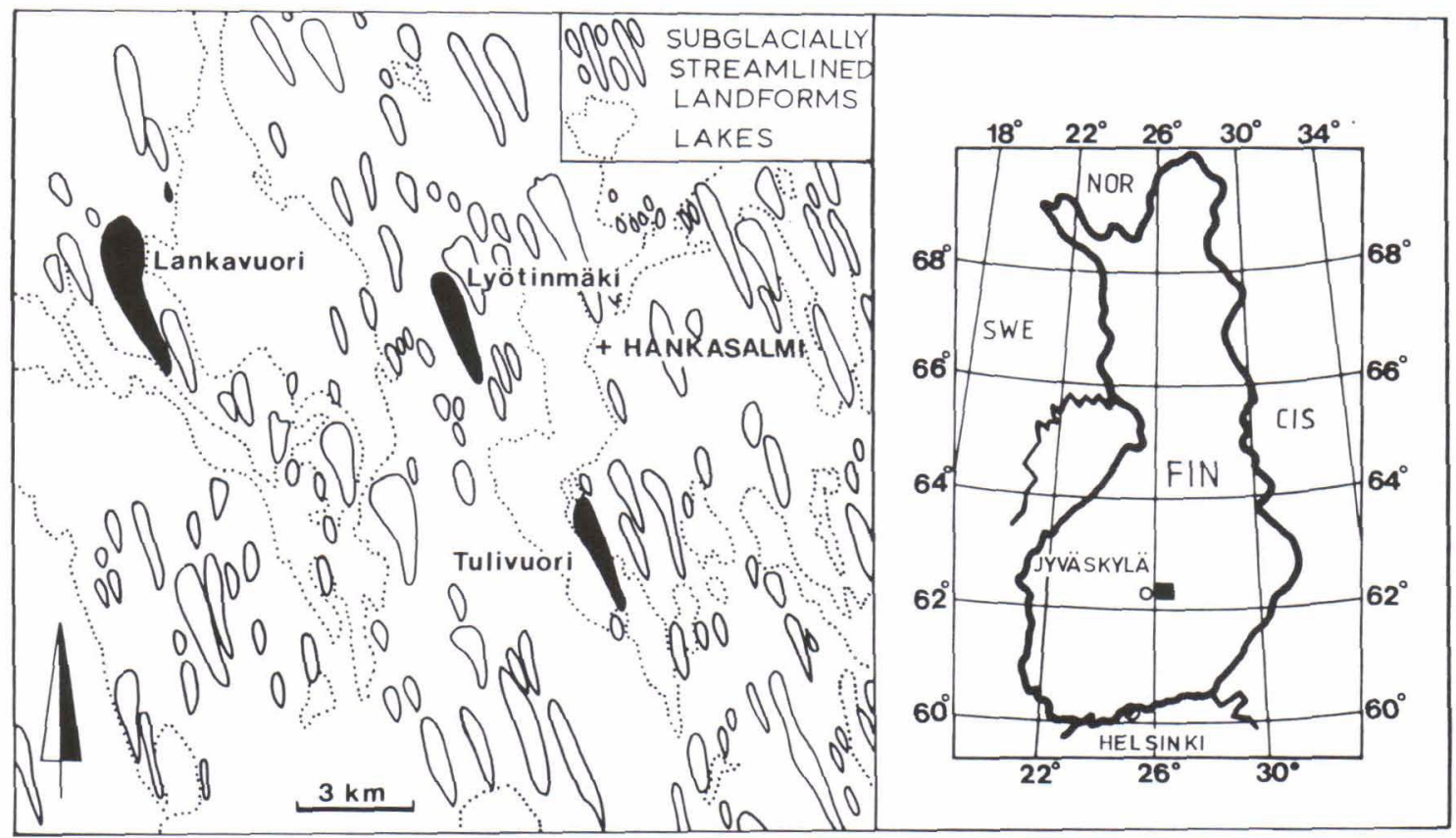

Fig. 1. The location of the study area.

\section{Investigation sites}

We chose three crag and tail ridges as investigation sites by basic map (1:20 000) interpretation. These crag and tail ridges are in Hankasalmi and Laukaa communes and their names are Lyötinmäki, Tulivuori and Lankavuori (Fig. 1). These crag and tail ridges had passable roads and their large size suggested that their tills might be thick.

Lyötinmäki is a three kilometre long crag and tail ridge. The width and height of its stoss side are $0.7 \mathrm{~km}$ and $75 \mathrm{~m}$, respectively (Fig. 2). The crag is partly exposed. The tail flanks are covered by shore deposits (washed till) which lie below the highest shoreline of the Baltic Sea (about 146 m a.s.l., Ristaniemi 1985, 1987). These shore deposits are marked with sand pits.

Tulivuori is distinctly lower than Lyötinmäki but in other respects of the same size. The crag is partly exposed. The crag summit is about 35 metres above the surrounding area (Fig. 3) and it is below the highest shoreline of the Baltic Sea (141 $\mathrm{m}$ a.s.1.). There are shore deposits (washed till) of the Ancient Lake Päijänne on the tail flanks below $101 \mathrm{~m}$ a.s.l. (Ristaniemi 1987).

Lankavuori is a large crag and tail ridge to the west of Lake Kynsivesi. It is $4 \mathrm{~km}$ in length and about $1 \mathrm{~km}$ in width. The crag is partly exposed and its summit is more than $110 \mathrm{~m}$ above the water level of Lake Kynsivesi. The tail is from 30 to $40 \mathrm{~m}$ above the surrounding area (Fig. 4). On the tail flanks there are shore deposits (washed till) with small sandpits. The highest shoreline of the Baltic Sea is about $155 \mathrm{~m}$ a.s.l. (Ristaniemi 1985, 1987).

\section{Methods}

In this study we used a 12-channel hammer refraction seismograph Geometrics ES-1225 (Fig. 5). This seismograph is equipped with a digital memory which enables stacking of more than one 


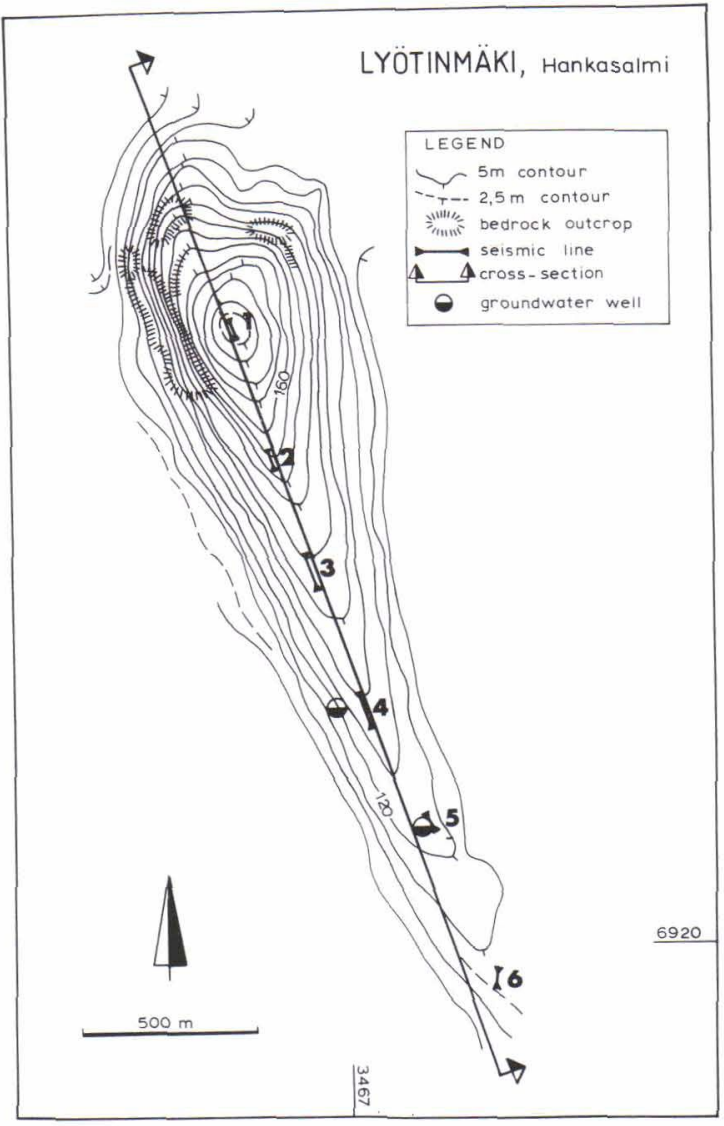

Fig. 2. The crag and tail of Lyötinmäki.

signal from an impact point. This means that the signals can be added to each other so that a series of identical weak signals can produce a strong final signal.

The seismic soundings were done with an inline profiling method. Most of the seismic lines were on roads or paths on the top of the ridges (Figs. 2, 3 and 4). Some lines were continuous whereas others were sporadic. The geophones were arranged at intervals of $5 \mathrm{~m}$, which means that the length of a single line was $55 \mathrm{~m}$. This 5 metre interval gives more exact information on soil and groundwater conditions than, for instance, a 10 metre interval. The offset impact points were generally 30 and/or $55 \mathrm{~m}$ beyond the

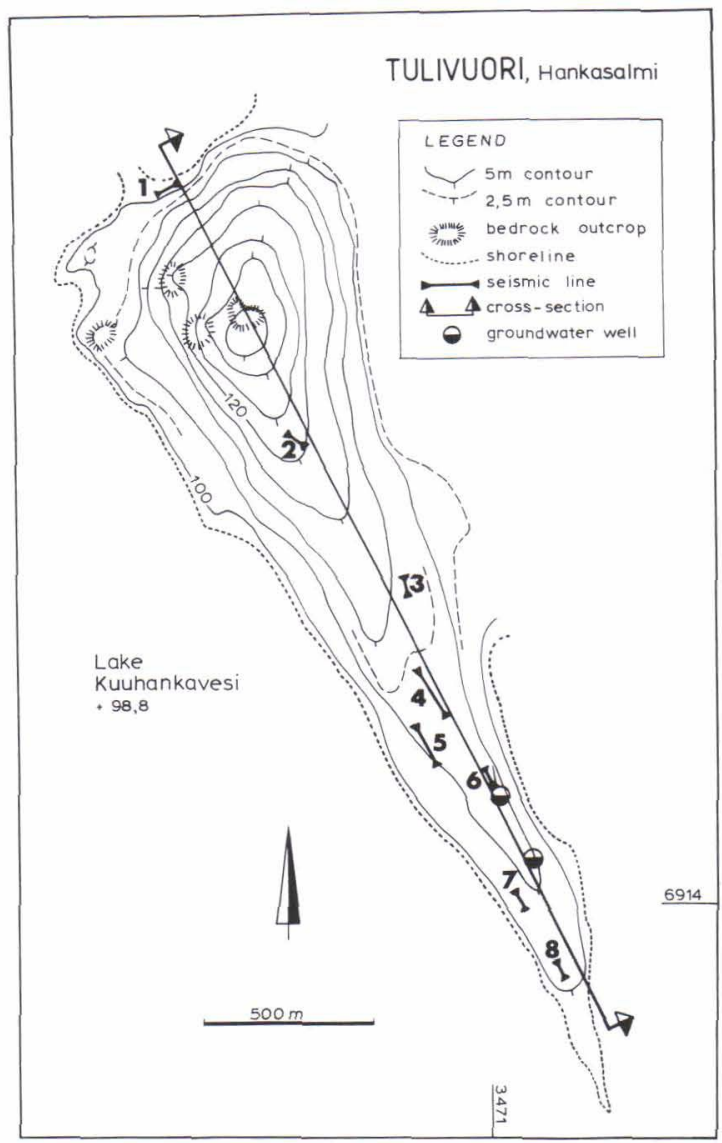

Fig. 3. The crag and tail of Tulivuori.

ends of the lines. Some offset impact points were 70 and $90 \mathrm{~m}$ beyond the ends of the lines. The longest distance between an impact point and the nearest geophone was $125 \mathrm{~m}$. Because of the remote location of the investigation sites and the fine weather, the background noise was minimal. Therefore, we could use maximum signal gains in the soundings. The soundings were done in August and September 1990 and in October 1991.

The seismic data was preliminarily interpreted in the field with a programmable pocket calculator. We picked up the travel time values (breaks) from the seismograph screen and drew the time-distance graphs by hand. The thicknesses of the soil layers at the ends of the seismic lines 


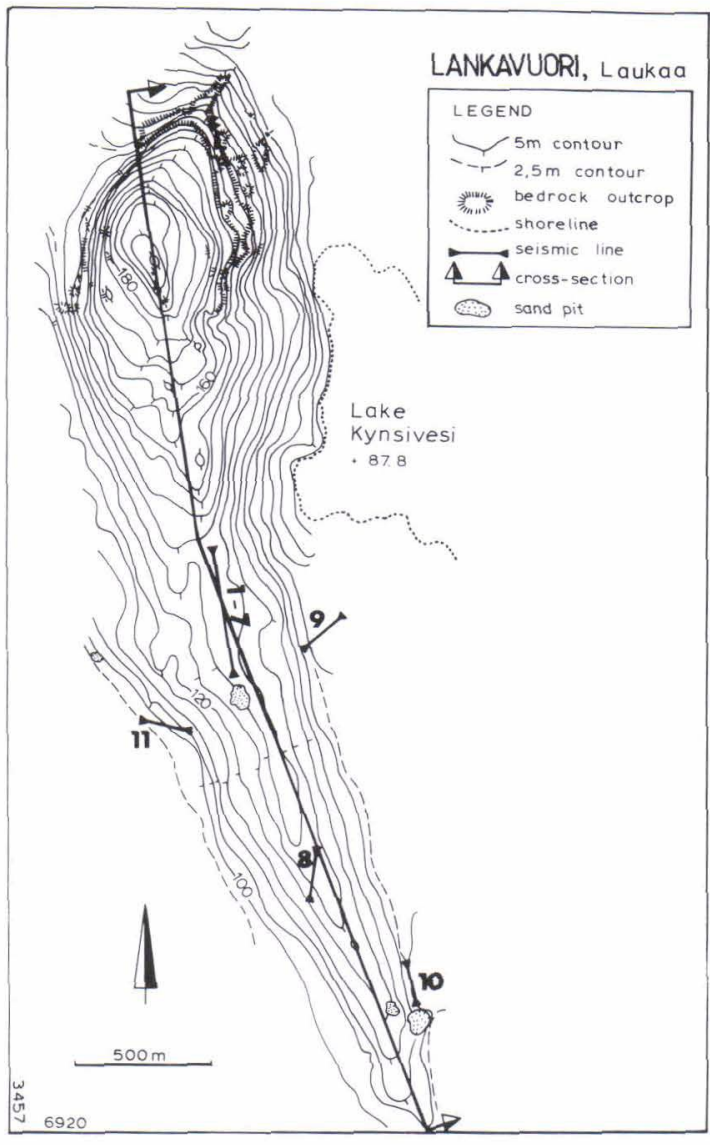

Fig. 4. The crag and tail of Lankavuori.

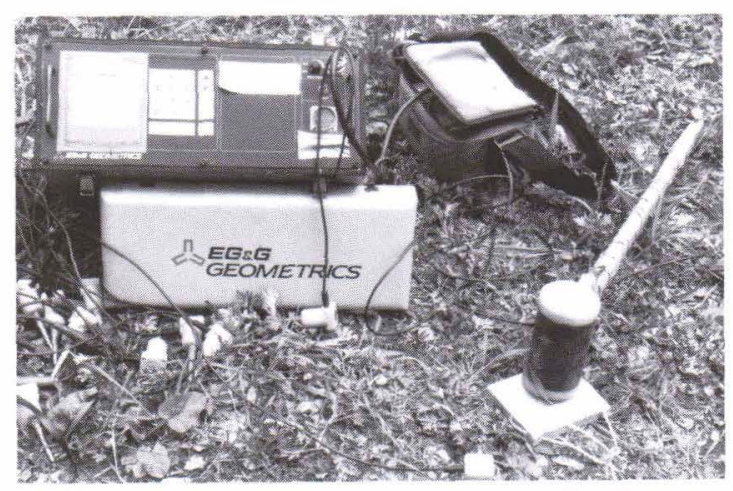

Fig. 5. The 12-channel hammer refraction seismograph. were calculated with the intercept time method. The true velocities of the soil layers and those of the bedrock were calculated, if possible, with the mean-minus-T -method (e.g. Mäkelä 1989, Sjögren 1984).

If the depth of the bedrock could not be directly calculated with the data from the end impact points, it was undirectly calculated with the data from the offset impact points. These calculations, however, require reliable bedrock travel times from the offset impact points. The data from these offset impact points were appended on the time-distance graphs of the end impact points as a function of the distance between the ends of the seismic lines and the offset impact points. This method can only be applied in areas where soil conditions do not vary significantly. Despite these restrictions, this method generally gives reliable information on the depths of bedrock (e.g. Saarenketo 1988).

Sometimes we received no bedrock travel time signals, not even from the offset impact points. In these cases the minimum depths of bedrock were calculated by appending imaginary bedrock velocity lines to the ends of the time-distance curves of the real data. When the bedrock velocities could not be calculated, we used $4000 \mathrm{~m} / \mathrm{s}$ as a bedrock velocity in our calculations. This value was chosen because it does not give too large soil thicknesses (Sjögren 1984).

The seismic results have not been checked with drillings for technical reasons. To control our interpretations we measured the groundwater levels of the wells situated on the ridges.

\section{Results}

\section{Lyötinmäki}

The supra-aquatic summit of Lyötinmäki is capped by a soil layer which is from 2 to $4 \mathrm{~m}$ thick (L1, Table 1, Fig. 6). The seismic soundings suggest that the layer contains no groundwater. At the lee side of the crag the thickness of soil in- 


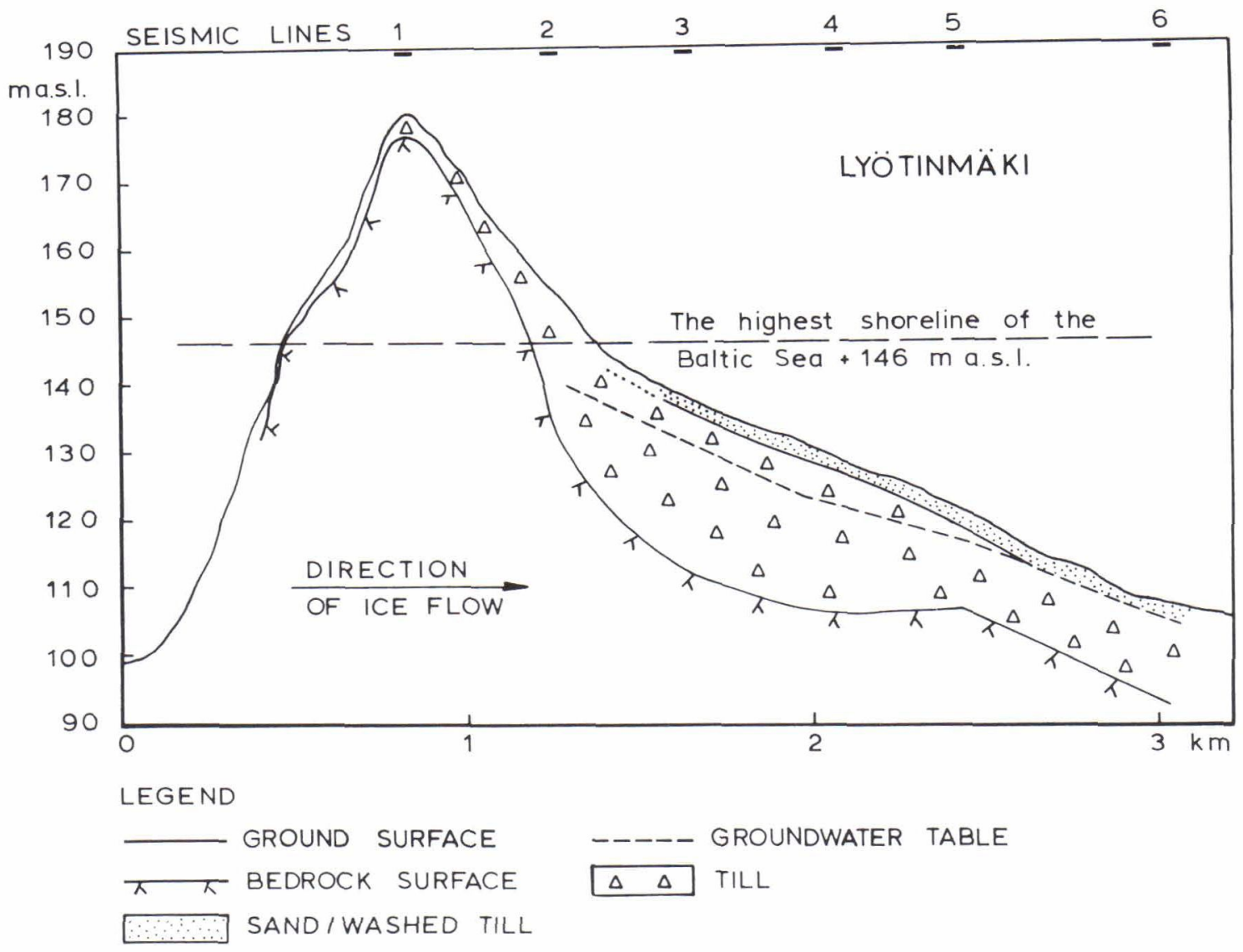

Fig. 6. The cross-section of Lyötinmäki.

creases clearly. The bedrock is at a depth from 20 to $24 \mathrm{~m}$ and the depth of the groundwater table is from 11 to $13 \mathrm{~m}$ below the seismic line 2 . Leewards from the seismic line 3 the seismic soundings showed a 2 metre thick surface layer (seismic velocity from 330 to $510 \mathrm{~m} / \mathrm{s}$ ). The seismic velocity of the unsaturated layer below the surface layer is from 870 to $1200 \mathrm{~m} / \mathrm{s}$. The seismic velocity of the saturated layer varies from 1900 to $2200 \mathrm{~m} / \mathrm{s}$ (seismic lines 3-6). At the end of the tail the groundwater table is from 1 to 3 $\mathrm{m}$ below the ground surface. The groundwater level of the well situated here is $1.4 \mathrm{~m}$ below the ground surface.

The bedrock is at its deepest from 20 to $26 \mathrm{~m}$ below the ground surface between the seismic lines 2 and 4 . The lee side of the crag (L2) is clearly more fractured (seismic velocity $3100 \mathrm{~m} / \mathrm{s}$ ) than the stoss side $(\mathrm{L} 1,4650 \mathrm{~m} / \mathrm{s})$.

\section{Tulivuori}

The summit of Tulivuori, which is more than $10 \mathrm{~m}$ below the highest shoreline of the Baltic Sea, is partly exposed. On the tail there is a surface layer between the seismic lines 2 and 8 . Its thickness varies from 1 to $3 \mathrm{~m}$ and seismic velocity from 340 to $510 \mathrm{~m} / \mathrm{s}$ (Fig. 7). The seismic velocity of the unsaturated layer below the surface layer varies from 750 to $1350 \mathrm{~m} / \mathrm{s}$ (Table 2). 
Table 1. The seismic results of Lyötinmäki ( $\ldots .=$ groundwater table).

\begin{tabular}{|c|c|c|c|}
\hline Seismic line & Seismic velocity $\mathrm{m} / \mathrm{s}$ & Thickness $\mathrm{m}$ & Interpretation \\
\hline \multirow[t]{2}{*}{1} & V1 $470-870$ & $2.5-3.9$ & Till \\
\hline & V2 4650 & depth $2.5-3.9$ & Bedrock \\
\hline \multirow[t]{4}{*}{2} & V1 $430-820$ & $1.2-4.3$ & Till \\
\hline & V2 $870-1020$ & $8.2-10.2$ & Till \\
\hline & V3 $1710-2050$ & $9.5-11.0$ & Till \\
\hline & V4 3100 & depth $20.5-24.0$ & Bedrock \\
\hline \multirow[t]{4}{*}{3} & V1 $390-510$ & 2.1 & Sand/washed till \\
\hline & $\mathrm{V} 21100-1200$ & 4.8 & Till $\ldots \ldots \ldots \ldots$ \\
\hline & V3 2200 & 19.3 & Till \\
\hline & V4 4000 & appr. depth 26.1 & Bedrock \\
\hline \multirow[t]{4}{*}{4} & V1 500 & 1.4 & Sand/washed till \\
\hline & V2 $920-1050$ & 4.9 & Till $\ldots \ldots \ldots \ldots$ \\
\hline & V3 1900 & 15.6 & Till \\
\hline & V4 3400 & depth 22.0 & Bedrock \\
\hline \multirow[t]{4}{*}{5} & V1 $330-450$ & $1.8-2.6$ & Sand/washed till \\
\hline & V2 $1350-1580 ?$ & $2.1-14.0 ?$ & Sand/loose till? \\
\hline & V3 2200 & 9.8 & Till \\
\hline & V4 4000 & appr. depth $14.4-15.8$ & Bedrock \\
\hline \multirow[t]{3}{*}{6} & $\mathrm{~V} 1360-460$ & 2.5 & Sand/washed till \\
\hline & V2 2000 & 12.3 & Till \\
\hline & V3 3700 & depth 14.7 & Bedrock \\
\hline
\end{tabular}

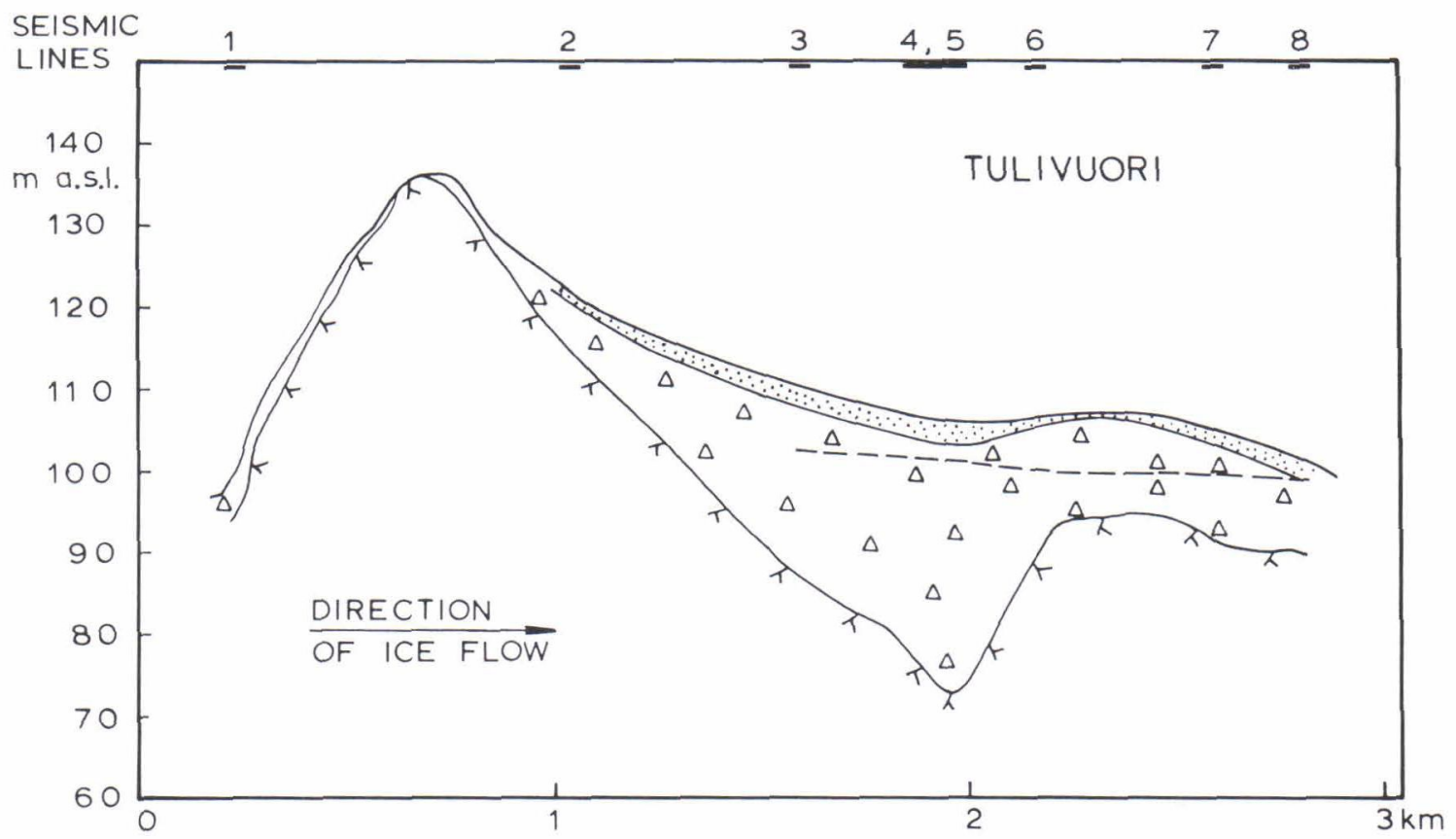

LEGEND

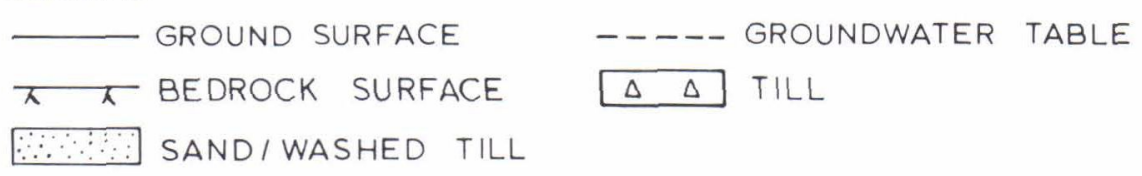

Fig. 7. The cross-section of Tulivuori. 
Table 2. The seismic results of Tulivuori $(\ldots .=$ groundwater table $)$.

\begin{tabular}{|c|c|c|c|}
\hline Seismic line & Seismic velocity $\mathrm{m} / \mathrm{s}$ & Thickness m & Interpretation \\
\hline \multirow[t]{3}{*}{1} & V1 390 & 1.7 & Sand/washed till \\
\hline & V2 2100 & 3.1 & Till \\
\hline & V3 4000 & appr. depth 4.7 & Bedrock \\
\hline \multirow[t]{3}{*}{2} & V1 $490-510$ & 1.4 & Sand/washed till \\
\hline & V2 $750-940$ & 5.2 & Till \\
\hline & V3 2750 & depth 6.6 & Bedrock \\
\hline \multirow[t]{4}{*}{3} & V1 $350-460$ & $2.4-2.6$ & Sand/washed till \\
\hline & $\mathrm{V} 21200-1220$ & $5.1-5.3$ & Till $\ldots \ldots \ldots \ldots$ \\
\hline & V3 $2040-2060$ & $12.0-13.5$ & Till \\
\hline & V4 5400 & depth $19.7-21.2$ & Bedrock \\
\hline \multirow[t]{4}{*}{4} & V1 430 & $2.1-2.5$ & Sand/washed till \\
\hline & V2 1200 & 2.8 & Till \\
\hline & V3 $1730-2000$ & $23.0-26.0$ & Till \\
\hline & V4 2700 & depth $28.0-30.0$ & Bedrock \\
\hline \multirow[t]{4}{*}{5} & V1 $490-500$ & 2.9 & Sand/washed till \\
\hline & $\mathrm{V} 21150-1350$ & 3.3 & Till $\ldots \ldots \ldots \ldots$ \\
\hline & V3 2150 & $25.0-26.0$ & Till \\
\hline & V4 4000 & appr. depth $32.0-33.0$ & Bedrock \\
\hline \multirow[t]{4}{*}{6} & V1 360 & 1.2 & Sand/washed till \\
\hline & V2 860 & 6.1 & Till $\ldots \ldots \ldots \ldots$ \\
\hline & V3 1930 & appr. 6.5 & Till \\
\hline & V4 4000 & appr. depth 13.7 & Bedrock \\
\hline \multirow[t]{4}{*}{7} & V1 $340-390$ & $2.0-2.1$ & Sand/washed till \\
\hline & V2 $1300-1750$ & $3.7-6.4$ & Sand/loose till \\
\hline & V3 2460 & $6.1-6.5$ & Till \\
\hline & V4 $4000-4900$ & depth $12.0-15.0$ & Bedrock \\
\hline \multirow[t]{3}{*}{8} & V1 350 & 2.5 & Sand/washed till \\
\hline & V2 1680 & 9.7 & Sand/loose till \\
\hline & V3 4000 & appr. depth 12.2 & Bedrock \\
\hline
\end{tabular}

The seismic velocity of the saturated layer varies from 1730 to $2460 \mathrm{~m} / \mathrm{s}$. In the seismic line 7 there is an additional layer (seismic velocity from 1300 to $1750 \mathrm{~m} / \mathrm{s}$ ) below the groundwater table. The gradient of the groundwater table of Tulivuori is lower than that of Lyötinmäki.

The soil is at its thickest between the seismic lines 4 and 5 . The bedrock is $33 \mathrm{~m}$ below the ground surface at its deepest. The bedrock rises sharply in the lee side of the ridge. This can also be seen in the field as a slight rise of the tail. The contours of the basic map, however, do not show this in any way. The groundwater levels of the wells in the tail of Tulivuori coincide with the water levels obtained by the soundings.

The lee side of the crag (L2) is very fractured and probably weathered (seismic velocity 2750 $\mathrm{m} / \mathrm{s})$.

\section{Lankavuori}

All the seismic lines are below the highest shoreline of the Baltic Sea. The seismic lines 1-8 are on the top of the ridge and the lines $9-11$ are 


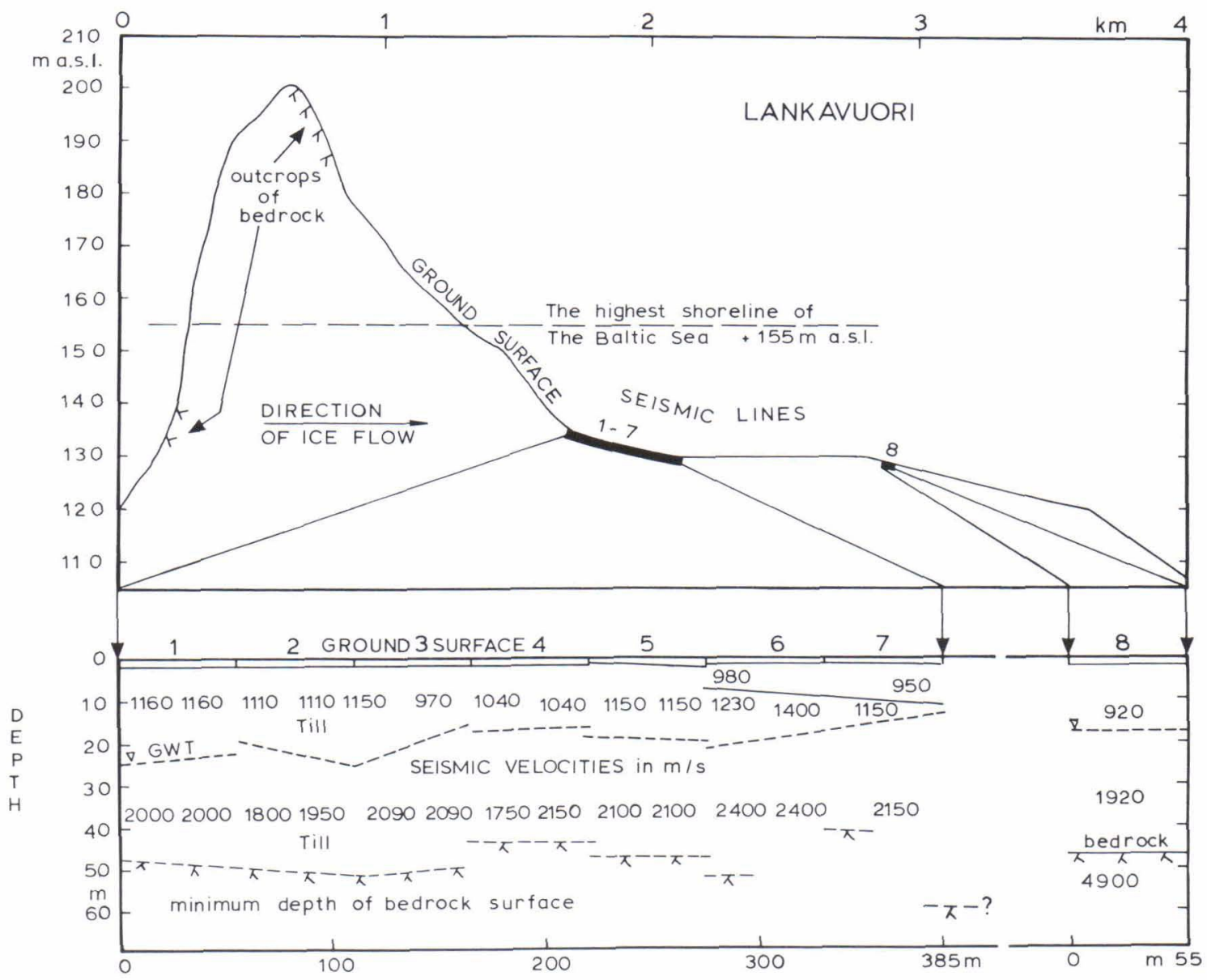

Fig. 8. The cross-section of Lankavuori.

on the flanks of the ridge (Fig. 4).

A from 1 to $2 \mathrm{~m}$ thick surface layer could be interpreted for all seismic lines. The seismic velocity of this layer is from 360 to $740 \mathrm{~m} / \mathrm{s}$. The surface layer is underlain by an unsaturated layer. The seismic velocity of this layer is from 970 to $1400 \mathrm{~m} / \mathrm{s}$ (Fig. 8). In addition there is a layer of lower seismic velocity (from 920 to $980 \mathrm{~m} / \mathrm{s}$ ) below the surface layer in the seismic lines $6-8$. Its thickness is from 6 to $17 \mathrm{~m}$. The depth of the groundwater table in the tail is from 14 to $24 \mathrm{~m}$. The seismic velocity of the saturated layer varies from 1750 to $2400 \mathrm{~m} / \mathrm{s}$.
The bedrock was not detected in the seismic lines $1-7$. The calculated minimum depth of bedrock was from 41 to $60 \mathrm{~m}$. The only reliable observation of the bedrock was from the seismic line 8 , where the bedrock is $47 \mathrm{~m}$ below the ground surface (Figs. 8 and 9).

At the flanks of the ridge the bedrock was detected only in the seismic line 11. The depth of bedrock is there $55 \mathrm{~m}$. This suggests that the depth of the bedrock at the top of the ridge is $85 \mathrm{~m}$ at its largest. This estimate is supported by the seismic soundings in the line 9 , where the soil is at least $43 \mathrm{~m}$ thick. 
Table 3. Seismic velocities m/s of soil and rock types above and below groundwater table. 1 and 2 are from Finnish studies and 3 is from Swedish studies (Lahermo \& Rainio 1972).

\begin{tabular}{|c|c|c|c|c|c|c|}
\hline \multirow{2}{*}{$\begin{array}{l}\text { Soil type, fraction, } \\
\text { rock }\end{array}$} & \multicolumn{3}{|c|}{ Seismic velocity above groundwater table } & \multicolumn{3}{|c|}{ Seismic velocity below groundwater table } \\
\hline & 1 & 2 & 3 & 1 & 2 & 3 \\
\hline humus-rich topsoil & $200-500$ & & $300-500$ & & & \\
\hline clay & \multirow{2}{*}{$\begin{array}{c}200-700 \\
(1500)\end{array}$} & \multirow{2}{*}{600} & $\begin{array}{c}300-600 \\
(1200)\end{array}$ & \multirow[t]{2}{*}{$1200-1800$} & \multirow{2}{*}{$1275-1600$} & $1100-1600$ \\
\hline fine, medium silt & & & \multirow[b]{2}{*}{$\begin{array}{c}500-800 \\
(1200)\end{array}$} & & & \\
\hline $\begin{array}{l}\text { coarse silt, } \\
\text { fine sand }\end{array}$ & \multirow{2}{*}{$200-800$} & \multirow{3}{*}{$\begin{array}{l}350-850 \\
400-950\end{array}$} & & \multirow{2}{*}{$1200-1800$} & \multirow{3}{*}{$1350-1850$} & $1200-1500$ \\
\hline $\begin{array}{l}\text { medium, coarse } \\
\text { sand }\end{array}$ & & & $300-500$ & & & $900-1500$ \\
\hline gravel & $400-1300$ & & $400-1200$ & $1200-1800$ & & $1200-2000$ \\
\hline loose sandy till & $200-1300$ & \multirow{2}{*}{$450-1300$} & $300-500$ & $1200-1800$ & \multirow{2}{*}{$1650-2100$} & $1200-1500$ \\
\hline $\begin{array}{l}\text { medium dense } \\
\text { sandy till }\end{array}$ & $700-1500$ & & $400-1200$ & $1300-2000$ & & $1200-1600$ \\
\hline $\begin{array}{l}\text { dense } \\
\text { sandy till }\end{array}$ & $\begin{array}{c}1500-2200 \\
(2700)\end{array}$ & & $1600-2800$ & $\begin{array}{c}2000-2500 \\
(2700)\end{array}$ & & $1600-2800$ \\
\hline $\begin{array}{l}\text { weathered } \\
\text { bedrock }\end{array}$ & $500-1500$ & & & $2700-4000$ & $\begin{array}{c}2600-3800 \\
(4000)\end{array}$ & $3000-4000$ \\
\hline granite, gneiss & & & & $4500-5700$ & $4100-5300$ & $4500-5900$ \\
\hline mica schist & & & & 4100 & & \\
\hline amfibolite, gabbro & & & & 6000 & $5600-5700$ & $5500-6000$ \\
\hline
\end{tabular}




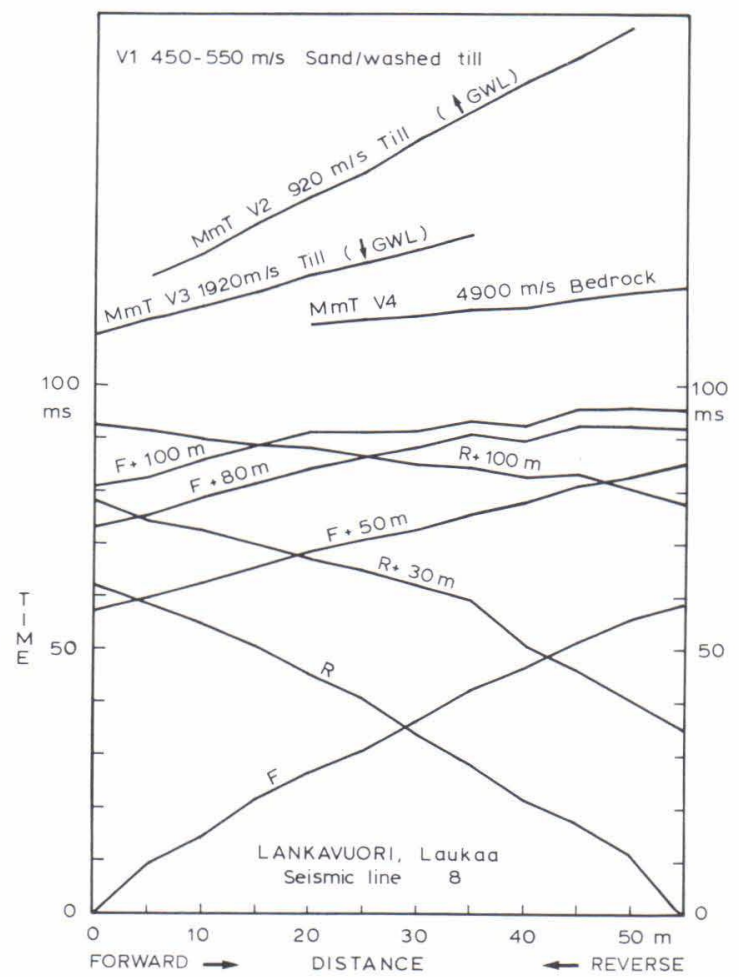

Fig. 9. The time-distance graph and the mean-minus-T -velocity curves for different layers in the seismic line 8 of Lankavuori.

\section{Conclusions}

The seismic velocities of the various layers correspond to those given in literature for sandy till (Table 3). The seismic velocities of the tills above the groundwater table are mainly from 900 to $1200 \mathrm{~m} / \mathrm{s}$. This means that the tills are comparatively loose. The seismic velocities of the tills below the groundwater table are generally from 2000 to $2200 \mathrm{~m} / \mathrm{s}$. This indicates that the tills are compact.

The seismic soundings also revealed the shore deposits on the crag and tail ridges. The thicknesses of the shore deposits vary from 1 to $3 \mathrm{~m}$ and their seismic velocities are from 330 to 870 $\mathrm{m} / \mathrm{s}$. The fractured bedrock at the lee sides of the crags reflects the intensity variations of the glacial erosion.
The groundwater table can lie deep below the ground surface in the tails. In Lankavuori, for instance, the calculated maximum depth of the groundwater table is $24 \mathrm{~m}$. This indicates that the tills have relatively high hydraulic conductivities. These are clearly lower, however, than those of esker soils (sand, gravel). Therefore, crag and tail ridges are not suitable for large-scale water supply. On the other hand, the groundwater intake of Leivonmäki commune is constructed in a crag and tail ridge. The yield of this intake is $60 \mathrm{~m}^{3} / \mathrm{d}$ (Keski-Suomen vesipiiri 1982). According to Salmi et al. (1991) the shore deposits of drumlins are in a key position when the groundwater resources are considered.

The calculated thicknesses of the tills in the ridges were $55 \mathrm{~m}$ at their largest. The tills in Lankavuori are probably even thicker than that, perhaps $85 \mathrm{~m}$. Such great thicknesses are, however, rare in crag and tail ridges. It is likely that the tills are at their thickest in large ridges. The thicknesses of the tills decrease leewards as the ridges get lower and merge into the surroundings.

Seismic sounding is a simple and effective preliminary method to investigate soil thicknesses. It is a valuable research method especially in till areas where drillings are often hindered by compactness of till and by cobbles and boulders. On the other hand the crag and tail ridges may contain, for instance, sorted deposits or lenses. These are not detected by seismic soundings if their seismic velocities are lower than those of tills. The coarseness and sorting of tills cannot be determined exclusively by seismic soundings.

The depths of bedrock obtained in this study are, so far, the record depths of hammer refraction seismics in Finland. The interpretations have not, however, been checked with drillings. In Lankavuori the depth of bedrock must be determined by explosive refraction seismics because of the great thicknesses of the tills.

Acknowledgements. Petri Tuominen assisted us in the field and Pirjo Schroderus drew the figures. 


\section{References}

Flint, R. F., 1971. Glacial and Quaternary Geology. John Wiley, New York, USA, 892 p.

Glückert, G., 1973. Two large drumlin fields in Central Finland. Fennia 120, 37 p.

Haavisto-Hyvärinen, M., 1987. Mapping of drumlins of the Mikkeli district, southeastern Finland, 295-307. In Menzies, J. \& Rose, J. (eds.), Drumlin Symposium. A. A. Balkema, Rotterdam, The Netherlands. 360 p.

-, Kielosto, S. \& Niemelä, J., 1989. Precrags and drumlin fields in Finland. Sedimentary Geology 62, 337-348.

Keski-Suomen vesipiiri, 1982. Tärkeät pohjavesialueet. Leivonmäen kuntakansio. Keski-Suomen vesipiiri, Jyväskylä.

Lahermo, P. \& Rainio, H., 1972. Seismiset refraktioluotaukset maa-ainesarvioinneissa ja pohjavesitutkimuksissa. (Summary: Seismic refraction determinations in sand and gravel inventory and ground water investigation). Geologi 24 (4), $41-47$.

Mäkelä, J., 1985. Keski-Suomen drumliinit. Unpublished map 1:400 000. Keski-Suomen vesipiiri. Jyväskylä.

-, 1988. Deglasiaatio Kinnulan-Pihtiputaan alueella KeskiSuomessa (Abstract: Deglaciation in the Kinnula-Pihtipudas area in Central Finland). Publications of the department of Quaternary geology, University of Turku 62. 39 p. with appendices.

—, 1989. Seisminen refraktioluotaus pohjavesiselvityksissä (Abstract: The seismic refraction method in ground water prospecting). Mimeograph Series of the National Board of Waters and the Environment 195, 45 p.

—, Ristaniemi, O. \& Vuorenmaa, J., 1990. Seismisiä luotauk- sia Vaasan läänin harjualueilla (Presentationsblad: Seismiska refraktionslodningar på åsområden i Vasa län). Vaasan läänin seutukaavaliitto. Sarja B:51, 27 p. with appendices.

Peltoniemi, M., 1988. Maa- ja kallioperän geofysikaaliset tutkimusmenetelmät. Otakustantamo, $411 \mathrm{p}$.

Ristaniemi, O., 1985. Keski-Suomen muinaisrannat. KeskiSuomen seutukaavaliitto. Julkaisu nro 73, sarja B, 38 p. with appendices.

—, 1987. Itämeren korkein ranta ja Ancylusraja sekä MuinaisPäijänne Keski-Suomessa (Abstract and summary: The highest shore and Ancylus limit of the Baltic Sea and the Ancient Lake Päijänne in Central Finland). Ann. Univ. Turkuensis, C 59, 102 p. with appendices.

—, Kasari, T. \& Mäkelä, J., 1991. Hiekka- ja soramuodostumien seismisistä nopeuksista Pohjanmaalla. (Abstract: On the seismic velocities of gravel and sand formations in Ostrobothnia). Publications of the department of Quaternary geology, University of Turku 73, 23 p.

Saarenketo, T. (ed.), 1988. Geofysikaalisten mittausten koulutus- ja neuvottelupäivät Rovaniemellä 18-20.4. 1988. Tie- ja vesirakennuslaitos, Lapin piiri, $105 \mathrm{p}$.

Salmi, M., Palmu, J-P. \& Pullinen, A., 1991. Drumliinien pohjavesioloista Hankasalmen - Keiteleen - Pieksämäen ja Kaavin alueilla, väliraportti vuosien 1989-1990 tutkimuksista. The Geological Survey of Finland, Regional office of Southern Finland, 55 p. with appendices.

Sjögren, B., 1984. Shallow Refraction Seismics. Chapman and Hall, London, New York, 268 p.

Received December 19, 1991

Revision accepted April 28, 1992 